\title{
ator humano
}

A confusão das fronteiras

\section{Tripé competitivo}

$\mathbf{U}$ ma vez assisti a uma palestra de Peter Drucker na qual ele alertava que o grande desafio das empresas, para 0 século $X X I$, não serão as máquinas, mas as pessoas. Porém, muitos dirigentes de corporações não compreenderam, e ainda não compreendem, 0 aviso do guru.

São poucas as empresas que fixam seu foco visando a garantir competitividade e desenvolvimento, na intensificação de seu maquinário, esquecendo-se de valorizar, seus investimentos no capital humano da organização.

Em termos de competitividade, a lógica da compra de máquinas ocorre de forma totalmente distinta da lógica da aquisição dos recursos humanos. Caso, por exemplo, a empresa tenha um concorrente com um maquinário superior ao seu, basta ter capital que, da noite para o dia, conseguirá obter a mesma tecnologia.

Entretanto, caso o concorrente tenha um quadro de profissionais altamente treinado, comprometido com os resultados da organização, engajado na missão, na visão enos valores da companhia, a organização em desvantagem, por mais capital que possua, não conseguirá, de repente, se igualar ao seu concorrente. Terá que passar um bom tempo investindo nas pessoas para recuperar o tempo perdido em relação àqueles que saíram na frente e perceberam o óbvio: hoje são as pessoas da empresa que fazem a diferença.

Os recursos humanos ajudam, e muito, na

Sérgio Amad Costa FGVEAESP que exista forte investimento em um tripé formado por treinamento, participação nos resultados e criatividade/inovação.

Em primeiro lugar, a empresa, sendo facilitadora e promotora do treinamento de seus profissionais, conseguirá trabalhar com colaboradores altamente qualificados, resultando em serviços/produtos com qualidade à altura ou superior à da concorrência. Em segundo, empresas que desenvolvem programas de participação financeira dos colaboradores em seus resultados conseguem deles um grau de comprometimento efetivamente mais elevado.

0 terceiro pé da estrutura competitiva está calcado no combate à mesmice, evitando um erro empresarial muito comum: esperar obter um resultado diferente, fazendo as coisas como sempre foram feitas. Assim, é necessária uma administração que favoreça novas idéias, incentivando a criatividade deseus profissionais, possibilitando que participem em todos os níveis hierárquicos da organização, opinando sobre formas de enfrentar e vencer a concorrência.

Esses três fatores humanos da competitividade são bem conhecidos. Na prática, porém, a situação é diferente: muitas empresas e seus gestores relutam sobre o modo de efetivamente alcançá-los. Para vencer essa lacuna entre discurso e prática, a dica é construir uma cultura sólida na organização, na qual o fator humano seja incorporado como um valor e faça parte integrante da estratégia do negócio. 